\title{
Interfacial stability of iron doped lanthanum strontium chromite and scandia stabilized zirconia in oxidizing and reducing atmosphere
}

\author{
Sapna Gupta ${ }^{\mathrm{a}}$, Jonathan Lane ${ }^{\mathrm{b}}$, Jamie Wilson $^{\mathrm{b}}$, Pawel Plonczak ${ }^{\mathrm{b}}$ and Prabhakar Singh ${ }^{\mathrm{a}, *}$ \\ ${ }^{a}$ Center for Clean Energy Engineering, Department of Materials Science and Engineering, University of \\ Connecticut, 44 Weaver Road, Storrs, CT 06269 \\ ${ }^{b}$ Praxair Inc., Tonawanda, $N Y$
}

\begin{abstract}
:
This study reports the interfacial stability of doped $\left(\mathrm{La}_{0.8} \mathrm{Sr}_{0.2}\right)_{0.95} \mathrm{Cr}_{0.7} \mathrm{Fe}_{0.3} \mathrm{O}_{3}$ (LSCF) and 10Sc1CeSZ system in oxidizing and reducing atmosphere for the application of oxygen transport membrane (OTM) device. Role of oxygen partial pressure $\left(\mathrm{PO}_{2}\right)$ on the interfacial stability of LSCF with $10 \mathrm{Sc} 1 \mathrm{CeSZ}$ is studied under OTM fabrication conditions $\left(1400^{\circ} \mathrm{C}, \mathrm{PO}_{2} \sim 0.21-10^{-10}\right.$ atm). Interfacial stability corresponding to the interaction between LSCF and 10Sc1CeSZ decreases with decrease in $\mathrm{PO}_{2}$. Interfacial study of LSCF with $10 \mathrm{Sc} 1 \mathrm{CeSZ}$ shows absence and presence of strontium zirconate $\left(\mathrm{SrZrO}_{3}\right)$ at the interface in oxidizing $\left(\mathrm{PO}_{2} \sim 0.21\right.$ atm) and reducing atmosphere $\left(\mathrm{PO}_{2} \sim 10^{-10}\right.$ atm $)$ at $1400^{\circ} \mathrm{C}$ respectively. Mechanism for the formation of $\mathrm{SrZrO}_{3}$ is reported.

* Corresponding author. Tel.: +1 860486 8379; fax: +1 8604868378.

Email address: singh@engr.uconn.edu (P. Singh)
\end{abstract}

Keywords: Oxygen transport membrane, LSCF/10Sc1CeSZ, Interfacial stability, Strontium zirconate and Oxygen partial pressure 


\section{Introduction}

Dense ceramic materials with high mixed ionic-electronic conductivity (MIEC) have shown promising potential for economic, clean and efficient oxygen separation from air [1-2]. Applications range from small-scale oxygen pumps which can be utilized in medical industries to large scale oxygen production system for coal gasification/combustion in power plants [3-7]. MIEC materials also finds application in chemical processing which includes the partial oxidation of hydrocarbons [1-2,8]. For example, oxygen transport membrane prepared with MIEC materials can be used to convert natural gas to value-added chemicals such as syngas which can be further processed for hydrogen production and liquid fuels [2,9-10].

An overview of MIEC materials for use in oxygen separation devices like OTMs and technology development was recently published [2]. Lanthanum chromite doped at A-site with strontium and B-site with iron $(\mathrm{La} \mathrm{Sr})(\mathrm{Cr}, \mathrm{Fe})_{3-\delta}$ is currently being investigated for use in membranes and fuel side electrodes for use in oxygen transport membrane (OTM) devices [2,1112]. It is reported that Fe-doping improves electrode performance in solid state electrochemical devices (e.g. SOFC) [13-14]. Lower polarization resistance is obtained for iron doped $\mathrm{La}_{0.75} \mathrm{Sr}_{0.25} \mathrm{Cr}_{0.5} \mathrm{Fe}_{0.5} \mathrm{O}_{3-\delta}$ (LSCF55) than $\mathrm{Mn}$-doped $\mathrm{La}_{0.75} \mathrm{Sr}_{0.25} \mathrm{Cr}_{0.5} \mathrm{Mn}_{0.5} \mathrm{O}_{3-\delta}$ (LSCM55) [13]. Furthermore, ionic conductivity of $(\mathrm{La} \mathrm{Sr})(\mathrm{Cr}, \mathrm{Fe})_{3-\delta}$ is found to be higher than acceptor-doped lanthanum chromites and $(\mathrm{La} \mathrm{Sr})(\mathrm{Cr}, \mathrm{Mn})_{3-\delta}(\mathrm{LSCM})$ [15-16]. However, the authors have noted that most of the literature exists on LSCF55 $[11,13,17]$. An oxygen permeation flux and oxygen ionic conductivity of $2.5 \times 10^{-7} \mathrm{~mol} \mathrm{~cm}^{-2} \mathrm{~s}^{-1}$ and $\sim 0.01 \mathrm{~S} / \mathrm{cm}$ were found at $950{ }^{\circ} \mathrm{C}$ under air/CO gradient [11]. On the other hand, it is reported that LSCF55 is not stable and partially decomposes into metallic iron along with some other unknown phases when exposed to pure $\mathrm{H}_{2}$ atmosphere at $950^{\circ} \mathrm{C}(30 \mathrm{~h})$ [17]. Fang et al. [17] have calculated the decomposition oxygen 
partial pressure of LSCF55 as $6.3 \times 10^{-28} \mathrm{~atm}$. Addition of a fluorite phase is required to achieve the higher ionic conduction and oxygen flux performance required for oxygen separation devices such as OTMs [2]. For instance, single phase $\mathrm{La}_{0.8} \mathrm{Sr}_{0.2} \mathrm{Cr}_{0.5} \mathrm{Fe}_{0.5} \mathrm{O}_{3-\mathrm{d}}$ perovskite exhibited an oxygen flux of $\sim 2.5 \times 10^{-7} \mathrm{~mol} \mathrm{~cm} \mathrm{~cm}^{-2}$ while flux of the $\mathrm{La}_{0.8} \mathrm{Sr}_{0.2} \mathrm{Cr}_{0.5} \mathrm{Fe}_{0.5} \mathrm{O}_{3-\mathrm{d}} / \mathrm{Zr}_{0.84} \mathrm{Y}_{0.16} \mathrm{O}_{1.92}$ composite exhibited a higher oxygen flux of $\mathrm{JO}_{2} \sim 2.6 \times 10^{-6} \mathrm{~mol} \mathrm{~cm}^{-2} \mathrm{~s}^{-1}$ under an air/CO gradient at $950^{\circ} \mathrm{C}[18-19]$.

Interfacial stability of $(\mathrm{La} \mathrm{Sr})(\mathrm{Cr}, \mathrm{Fe})_{3-\delta}$ based materials with fluorite phase is not reported in literature under fabrication conditions $\left(1400^{\circ} \mathrm{C}, 0.21-10^{-10} \mathrm{~atm}\right)$ required for oxygen separation devices like OTMs. Due to the reported lower stability of higher Fe-containing LSCF perovskites, this study examines $\left(\mathrm{La}_{0.8} \mathrm{Sr}_{0.2}\right)_{0.95} \mathrm{Cr}_{0.7} \mathrm{Fe}_{0.3} \mathrm{O}_{3}$ and $10 \mathrm{Sc} 1 \mathrm{CeSZ}$ system with higher Cr: Fe ratio and lower Fe doping level. It is important to understand the interaction between LSCF perovskite and 10Sc1CeSZ fluorite under OTM processing which have not been reported upon in the literature [2]. This study, therefore, focuses on the interfacial stability of LSCF with 10Sc1CeSZ in oxidizing and reducing atmosphere under OTM fabrication conditions.

\section{Experimental Procedure}

\section{1. $\left(\mathrm{La}_{0.8} \mathrm{Sr}_{0.2}\right)_{0.95} \mathrm{Cr}_{0.7} \mathrm{Fe}_{0.3} \mathrm{O}_{3-\delta}$ and $10 \mathrm{Sc} \mathrm{CeSZ}$ synthesis}

Pellets of $10 \mathrm{Sc} 1 \mathrm{CeSZ}$ fluorite were made and then calcined at $1100^{\circ} \mathrm{C}$ for $2 \mathrm{~h}$. $\left(\mathrm{La}_{0.8} \mathrm{Sr}_{0.2}\right)_{0.95} \mathrm{Cr}_{0.7} \mathrm{Fe}_{0.3} \mathrm{O}_{3-\delta}$ (LSCF) powder was received from Praxair Inc. LSCF composition ink was prepared using Fuel Cell Materials ink vehicle. The LSCF ink was then screen printed onto the $10 \mathrm{Sc} 1 \mathrm{CeSZ}$ disk shaped pellet and dried at $125^{\circ} \mathrm{C}$ for $2 \mathrm{~h}$. The LSCF/10Sc1CeSZ system was then processed at $1400^{\circ} \mathrm{C}$ for $10 \mathrm{~h}$ in oxidizing (air) and reducing $\left(\mathrm{Ar}-3 \% \mathrm{H}_{2}-3 \% \mathrm{H}_{2} \mathrm{O}\right)$ atmosphere. 


\subsection{Characterization}

Microstructural changes, elemental analysis and third phase formation of the processed samples were analyzed using scanning electron microscope (SEM) (FEI - ESEM Quanta 250, Hillsboro, $\mathrm{OH}$ ) with energy dispersive spectroscopy (EDS). Elemental compositional analysis was further conducted using energy dispersive spectroscopy (EDS) attached to the transmission electron microscopy (TEM). Focused Ion Beam (FEI Strata 400S DUALBEAM FIB) was used for the sample preparation of LSCF73/10Sc1CeSZ for the TEM elemental analysis.

\section{Results and Discussion}

\subsection{Interfacial stability}

Single phase LSCF was screen-printed on a $10 \mathrm{Sc1CeSZ}$ disk and processed in oxidizing (air, $\mathrm{PO}_{2} \sim 0.21 \mathrm{~atm}$ ) and reducing atmosphere $\left(\mathrm{Ar}-3 \% \mathrm{H}_{2}-3 \% \mathrm{H}_{2} \mathrm{O}, \mathrm{PO}_{2} \sim 10^{-10}\right.$ atm) at $1400^{\circ} \mathrm{C}$. Fig. 1 shows the SEM micrographs of LSCF screen printed on 10Sc1CeSZ disk and sintered in air (Fig. 1a) and $\mathrm{Ar}-3 \% \mathrm{H}_{2}-3 \% \mathrm{H}_{2} \mathrm{O}$ (Fig. 1b). No third phase formation is identified in the bulk or LSCF/10Sc1CeSZ interface when processed in oxidizing atmosphere. However, a uniform and dense layer with a thickness of $\sim 1.7 \mu \mathrm{m}$ is found at the interface between LSCF and 10Sc1CeSZ indicating to an interaction between LSCF and $10 \mathrm{Sc} 1 \mathrm{CeSZ}$ in a reducing atmosphere. SEM-EDS spot analysis indicates that the interfacial layer is enriched in $\mathrm{Sr}$ and $\mathrm{Zr}$ in the ratio of approximately 1:1 indicating the formation of $\mathrm{SrZrO}_{3}$. Elemental mapping (Fig. 2) and line profile (Fig. 3) showed $\mathrm{Sr}$ and $\mathrm{Zr}$ enrichment at the interface of LSCF and 10Sc1CeSZ in Ar$3 \% \mathrm{H}_{2}-3 \% \mathrm{H}_{2} \mathrm{O}$ atmosphere, but not in air. A line profile of LSCF/10Sc1CeSZ system shows two zones (LSCF and 10Sc1CeSZ) when exposed to air as shown in Fig. 3a. However, three zones (LSCF, $\mathrm{SrZrO}_{3}$ and $10 \mathrm{Sc} 1 \mathrm{CeSZ}$ ) are identified in samples processed in a reducing gas 
atmosphere (Fig. 3b). Interaction of LSCF and $10 \mathrm{Sc} 1 \mathrm{CeSZ}$ results in to the intermediate zone of $\mathrm{SrZrO}_{3}$ phase as shown in Fig. 3b.

The electrical conductivity of $\mathrm{SrZrO}_{3}$ phase is $\sim 10^{-3}$ and $10^{-6} \mathrm{~S} \mathrm{~cm}^{-1}$ at $1000^{\circ} \mathrm{C}$ in air and reducing atmosphere $\left(10^{-16} \mathrm{~atm}\right)$ respectively [20]. This is significantly lower than the conductivity of $10 \mathrm{ScSZ}$ which is $0.3 \mathrm{~S} \mathrm{~cm}^{-1}$ at $1000^{\circ} \mathrm{C}$ [21]. Due to the formation of the insulating phase at the LSCF and 10Sc1CeSZ interface, fast degradation and lower performance is expected for oxygen separation devices incorporating LSCF/10Sc1CeSZ system. The third phase would act as a barrier to the ion conduction and greatly increase the overall cell resistance, causing low performance and durability. The thermal expansion coefficient of $\mathrm{SrZrO}_{3}\left(2.6 \times 10^{-5}\right.$ $\left.\mathrm{K}^{-1}\right)$ is lower than $10 \mathrm{ScSZ}\left(10.3 \times 10^{-6} \mathrm{~K}^{-1}\right)$ [22]. This can generate stress and small cracks over time leading to failure.

\subsection{Reaction mechanism for $\mathrm{SrZrO}_{3}$ formation in reducing atmosphere:}

The interaction between the perovskite and fluorite resulting in the formation of $\mathrm{La}_{2} \mathrm{Zr}_{2} \mathrm{O}_{7}$ and/or $\mathrm{SrZrO}_{3}$ is well documented in the literature for lanthanum strontium manganite (LSM)/YSZ system [23-24]. The reported mechanism suggests that interaction between perovskite and fluorite phases proceeds by the unidirectional diffusion of manganese into YSZ. At lower $\mathrm{PO}_{2}$, the solubility of $\mathrm{Mn}$ with lower valence state and larger ionic radii is higher than Mn with higher valence state [25-26]. After Mn diffuses from the B-site into YSZ, LSM perovskite gets enriched on the A-site resulting into $\mathrm{La} / \mathrm{Sr}$ interaction with $\mathrm{Zr}$ at the interface of $\mathrm{LSM} / 8 \mathrm{YSZ}$ and the formation of $\mathrm{La}_{2} \mathrm{Zr}_{2} \mathrm{O}_{7}$ and/or $\mathrm{SrZrO}_{3}$ [23-24]. Similar results have been reported for the case of LSCM/8YSZ and LSCM/10ScSZ [27]. Strontium zirconate formation is identified at the interface of $\mathrm{LSCM}$ and $8 \mathrm{YSZ} / 10 \mathrm{ScSZ}$ at lower $\mathrm{PO}_{2}$ due to the $\mathrm{Mn}^{4+} \rightarrow \mathrm{Mn}^{3+} \rightarrow \mathrm{Mn}^{2+}$ reduction and higher solubility of reduced $\mathrm{Mn}$ with larger radii. 
An identical mechanism for $\mathrm{SrZrO}_{3}$ formation is proposed for $\mathrm{LSCF} / 10 \mathrm{Sc} 1 \mathrm{CeSZ}$ composite systems where presence and migration of iron in LSCF is considered to play a significant role in the formation of $\mathrm{SrZrO}_{3}$ in reducing atmosphere. Iron tends to reduce its valence state from $\mathrm{Fe}^{4+} \rightarrow \mathrm{Fe}^{3+}$ (Eq. (1)) and $\mathrm{Fe}^{3+} \rightarrow \mathrm{Fe}^{2+}$ (Eq. (2)) in reducing atmospheres and the charge is balanced by oxygen vacancies as shown below:

$$
\begin{aligned}
& \frac{1}{2} \mathrm{O}_{2}+\mathrm{V}_{\mathrm{O}}^{\prime \prime}+2 \mathrm{Fe}_{\mathrm{Fe}}^{\times}=\mathrm{O}_{\mathrm{O}}^{\times}+2 \mathrm{Fe}_{\mathrm{Fe}}^{-} \\
& \frac{1}{2} \mathrm{O}_{2}+\mathrm{V}_{\mathrm{O}}^{\prime \prime}+2 \mathrm{Fe}_{\mathrm{Fe}}^{\prime}=\mathrm{O}_{\mathrm{O}}^{\times}+2 \mathrm{Fe}_{\mathrm{Fe}}^{\times}
\end{aligned}
$$

where $\mathrm{Fe}_{\mathrm{Fe}}^{\times}$refers to $\mathrm{Fe}^{3+}$ on $\mathrm{Fe}^{3+}$ sites, $\mathrm{Fe}_{\mathrm{Fe}}^{\cdot}$ refers to $\mathrm{Fe}^{4+}$ on $\mathrm{Fe}^{3+}$ sites, $\mathrm{Fe}_{\mathrm{Fe}}^{\prime}$ refers to $\mathrm{Fe}^{2+}$ on $\mathrm{Fe}^{3+}$ sites, and $\mathrm{V}_{\mathrm{O}}^{*}$ refers to oxygen vacancy with two positive charges.

Ionic radii variation occur with change in the valence state of $\mathrm{Fe}[2,27]$. Based on the LSM/8YSZ, LSCM/8YSZ and LSCM/10ScSZ literature report on diffusion and higher solubility of Mn (transition metal) into fluorite phase with lower oxidation state [25-27], it is hypothesized that $\mathrm{Fe}$ (transition metal) diffusion into $10 \mathrm{Sc} 1 \mathrm{CeSZ}$ is higher in reducing atmosphere with lower $\mathrm{PO}_{2}$ on comparison with oxidizing atmosphere with higher $\mathrm{PO}_{2}$. This is attributed to higher solubility of $\mathrm{Fe}$ into the zirconate with lower oxidation state and larger ionic radii when compared to Fe with higher oxidation state. The chemical diffusion coefficient of Fe in 8YSZ is $\sim 10^{-11} \mathrm{~cm}^{2} / \mathrm{sec}$ at $1000^{\circ} \mathrm{C}$ [28]. To confirm the Fe diffusion into the $10 \mathrm{Sc} 1 \mathrm{CeSZ}$ phase in reducing atmosphere, TEM-EDS spot analysis was conducted on the focused ion beam crosssectioned LSCF/10Sc1CeSZ system after exposure to reducing atmosphere at $1400^{\circ} \mathrm{C}$. 5-7 at. \% of $\mathrm{Fe}$ is identified in $10 \mathrm{Sc} 1 \mathrm{CeSZ}$ corresponding to $\mathrm{Fe}$ diffusion from the perovskite phase to fluorite phase in reducing atmosphere. Likewise for the LSM/8YSZ and LSCM/8YSZ system, Fe 
diffuses into $10 \mathrm{Sc} 1 \mathrm{CeSZ}$ and the perovskite lattice is then enriched on the A-site and therefore, $\mathrm{Sr}$ from the A-site reacts with $\mathrm{Zr}$ in $10 \mathrm{Sc} 1 \mathrm{CeSZ}$ resulting in the formation of $\mathrm{SrZrO}_{3}(\mathrm{SZO})$. Fig. 4 shows a schematic of mechanistic steps for $\mathrm{SrZrO}_{3}$ formation in reducing atmosphere. Step 1 shows an initial stage of LSCF/10Sc1CeSZ system heating to reaction temperature. Diffusion assisted changes occur in step 2. Fe reduction occurs $\left(\mathrm{Fe}^{4+} \rightarrow \mathrm{Fe}^{3+} \rightarrow \mathrm{Fe}^{2+}\right)$ and therefore, $\mathrm{Fe}$ diffuses from the LSCF lattice into 10Sc1CeSZ due to the higher solubility of reduced $\mathrm{Fe}$ into the fluorite phase. In step 3, LSCF perovskite lattice is A-site enriched after the Fe-diffusion. Subsequently, in step 4, $\mathrm{Sr}$ from the A-site reacts with $\mathrm{Zr}$ to form $\mathrm{SrZrO}_{3}$ at the interface of LSCF/10Sc1CeSZ.

\section{Conclusion}

Interfacial stability of $\left(\mathrm{La}_{0.8} \mathrm{Sr}_{0.2}\right)_{0.95} \mathrm{Cr}_{0.7} \mathrm{Fe}_{0.3} \mathrm{O}_{3}$ (LSCF)/10Sc1CeSZ system has been studied under $\mathrm{OTM}$ processing $\left(1400^{\circ} \mathrm{C}\right.$ and $\mathrm{PO}_{2} \sim 0.21-10^{-10}$ atm $)$ conditions. $\mathrm{SrZrO}_{3}$ formation is identified in the samples processed at lower $\mathrm{PO}_{2}$. When processed in oxidizing atmosphere, interface layer formation of $\mathrm{SrZrO}_{3}$ is not observed in the LSCF/10Sc1CeSZ system. TEM elemental analysis exhibits 5-7 at. \% of $\mathrm{Fe}$ in the $10 \mathrm{Sc} 1 \mathrm{CeSZ}$ phase attributed to Fe diffusion from perovskite (LSCF) to fluorite (10Sc1CeSZ) lattice. Mechanism for the formation of $\mathrm{SrZrO}_{3}$ is proposed for iron doped lanthanum strontium chromite and scandia stabilized zirconia system in reducing atmosphere.

\section{Acknowledgements}

The authors acknowledge the Center for Clean Energy Engineering at the University of Connecticut for testing and characterization facility. Financial support from The US 
Department of Energy (DOE) under a sub-contract to a cooperative agreement between Praxair, Inc. and DOE, contract number DE-FC26-07NT43088 is acknowledged. 


\section{References:}

[1] H.J.M. Bouwmeester, A.J. Burggraaf, in: A.J. Burggraaf, L. Cot (Eds.), Membrane Science and Technology Series, Elsevier, Amsterdam, 1996, pp. 435-510.

[2] S. Gupta, M.K. Mahapatra, P. Singh, Materials Science and Engineering R 90 (2015) 1-36.

[3] M. Liu, A.V. Joshi, Y. Shen, K. Krist, US Patent 5,273,628, 1993.

[4] R.M. Thorogood, Developments in air separation. Gas Sep. Purif. 5 (1991) 83-94.

[5] E.A. Hazbun, US Patent 4,791,079, 1988.

[6] W. Wang, Y.S. Lin, J. Membr. Sci. 103 (1995) 219-233.

[7] J.E. ten Elshof, H.J.M. Bouwmeester and H. Verweji, Appl. Catal. A: General 130 (1995) 195-212.

[8] S.P.S. Badwal, F.T. Ciacchi, Adv Mater. 13 (2001) 993-96.

[9] S. Pei, M.S. Kleefisch, T.P. Kobylinski, K. Faber, C.A. Udovich, V. Zhang-McCoy, B.Dabrowski, U. Balachandran, R.L. Mieville, R.B. Poeppel, Catal. Lett. 30 (1995) 201-212.

[10] U. Balachandran, J.T. Dusek, S.M. Sweeney, R.B. Poeppel, R.L. Mieville, P.S. Maiya, M.S. Kleefisch, S. Pei, T.P. Kobylinski, C.A. Udovich, A.C. Bose, Am. Ceram. Soc. Bull. 74 (1995) $71-75$.

[11] W. He, H. Huang, M. Chen, J.F. Gao, C.S. Chen, Solid State Ionics 260 (2014) 86-89. [12] A.A. Yaremchenko, V.V. Kharton, V.A. Kolotygin, M.V. Patrakeev, E.V. Tsipis, J.C. Waerenborgh, J. Power Sources 249 (2014) 483-496.

[13] J. Pẽna-Martinez, D. Marrero-Lopez, D. Perez-Coll, J.C. Ruiz-Morales, P. Nũnez, Electrochim. Acta 52 (2007) 2950.

[14] J.M. Haag, B.D. Madsen, S.A. Barnett, K.R. Poeppelmeier, Electrochem. Solid State Lett. 11 (2008) B51.

[15] D.K. Lee, H.I. Yoo, J. Electrochem. Soc. 147 (2000) 2835. 
[16] V.V. Kharton, E.V. Tsipis, I.P. Marozau, A.P. Viskup, J.R. Frade, J.T.S. Irvine, Solid State Ionics 178 (2007) 101.

[17] W. Fang, Y. Zhang, J. Gao, C. Chen, Ceramics International 40 (2014) 799-803.

[18] J.J. Liu, T. Liu, W.D. Wang, J.F. Gao, C.S. Chen, J. Membr. Sci. 389 (2012) 435-440.

[19] W. He, H. Huang, M. Chen, J.F. Gao, C.S. Chen, Solid State Ionics 260 (2014) 86-89.

[20] Nongluck P. Suriyayothin, PhD thesis, 1984.

[21] Y. Arachi, H. Sakai, O. Yamamoto, Y. Takeda, N. Imanishai, Solid State Ionics 121 (1999)

$133-139$

[22] D. Ligny, P. Richet, Physical Rev. B 53 (1996) 3013-3022.

[23] M. Chen, PhD thesis, Zurich, 2005

[24] C. Levy, Y. Zhong, C. Morel, J. Electrochemical Society 157 (2010) B1597-B1601.

[25] N. Li, M. Mahapatra, P. Singh, J. Power Sources 221 (2013) 57-63.

[26] J.W. Stevenson, P.F. Hallman, T.R. Armstrong, L.A. Chick, J. Am. Ceram. Soc. 78 (1995) 507-512.

[27] S. Gupta, Development of Perovskite/Fluorite based Materials for Oxygen Transport

Membrane System. Doctoral Dissertations 2015,

http://digitalcommons.uconn.edu/dissertations/799.

[28] M.B. Ricoult, M. Badding, Y. Thibault, Advances in Electronic and Electrochemical Ceramics. Ceramics Transactions 179 (2005) 173. 


\section{Figure Captions}

Fig. 1. SEM micrograph of LSCF screen printed on 10Sc1CeSZ and processed in: (a) air and (b) Ar$3 \% \mathrm{H}_{2}-3 \% \mathrm{H}_{2} \mathrm{O}$.

Fig. 2. SEM-EDS elemental mappings of LSCF screen printed on 10Sc1CeSZ and processed in air and $\mathrm{Ar}-3 \% \mathrm{H}_{2}-3 \% \mathrm{H}_{2} \mathrm{O}$ : (a, c) secondary electron image and (b, d) elemental mapping.

Fig. 2. SEM-EDS elemental line profiles of LSCF screen printed on 10Sc1CeSZ and processed in: (a) air and (b) $\mathrm{Ar}-3 \% \mathrm{H}_{2}-3 \% \mathrm{H}_{2} \mathrm{O}$.

Fig. 4. Schematic of reaction steps for the formation of $\mathrm{SrZrO}_{3}$ in reducing atmosphere. 

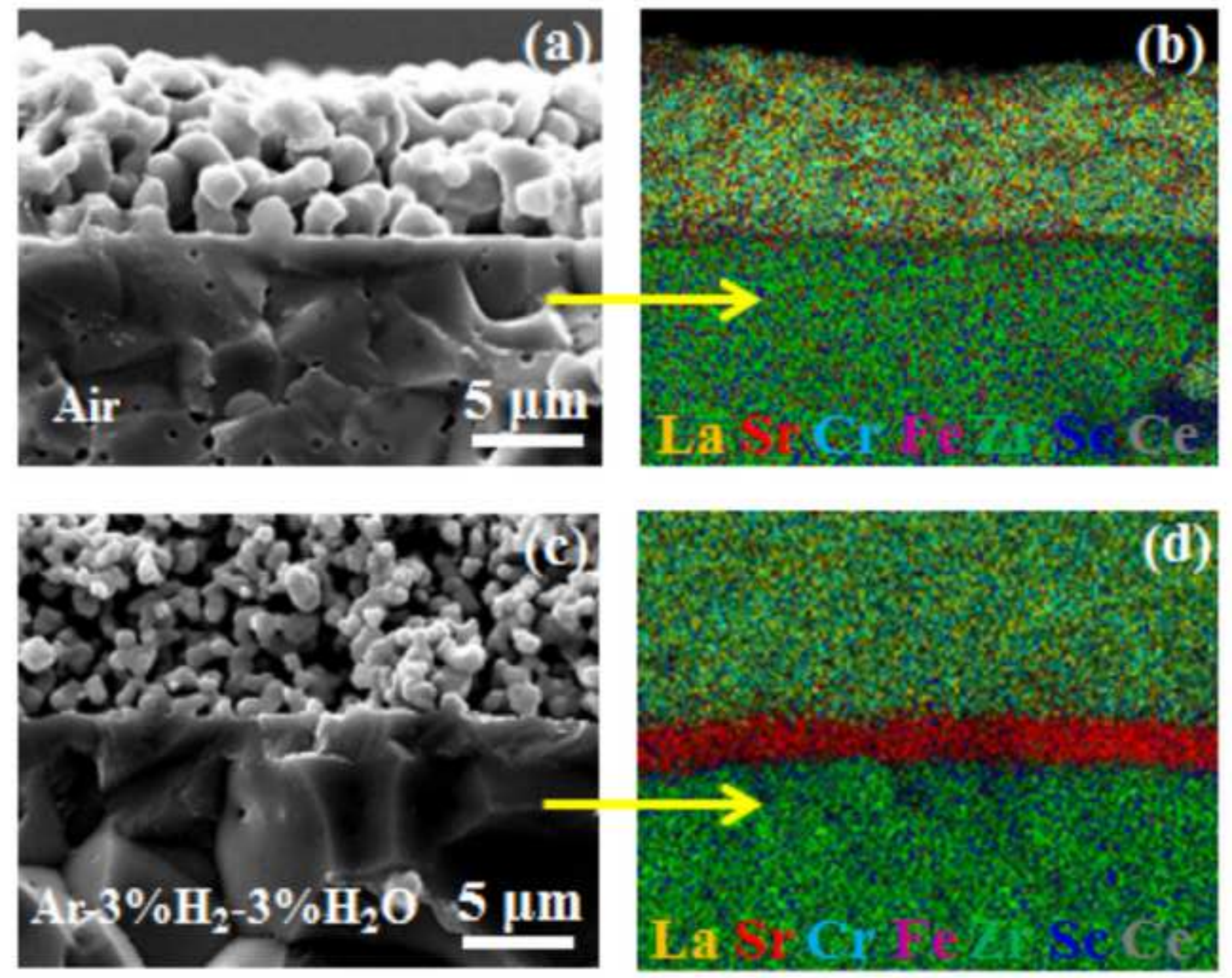

(d) 

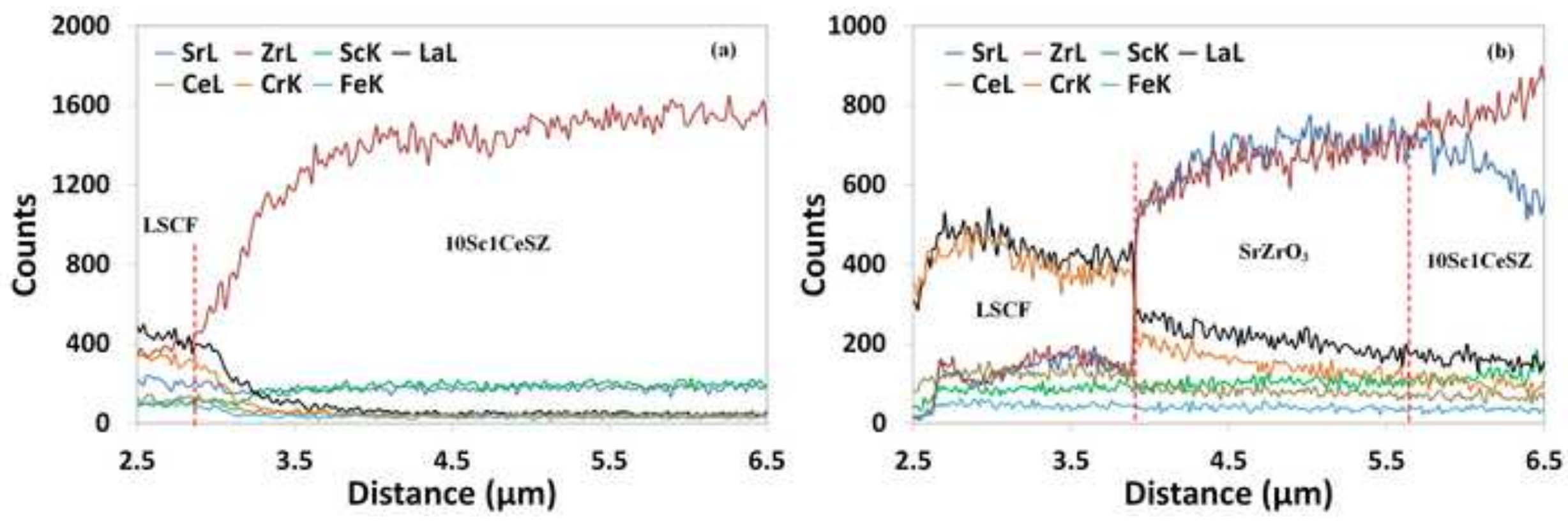


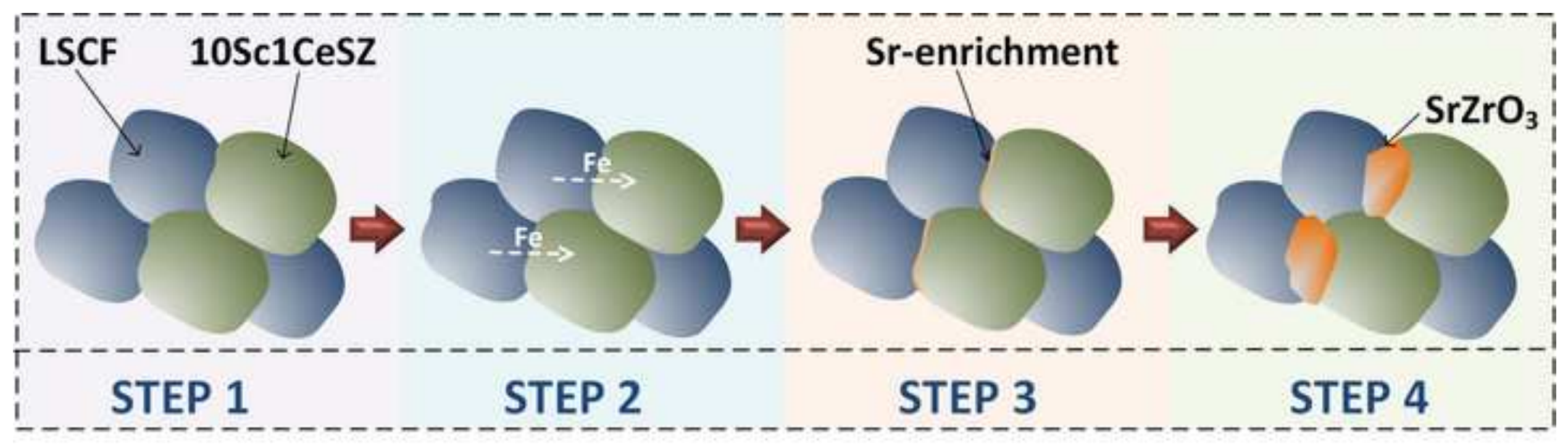

